\title{
ARAŞTIRMA | RESEARCH \\ Relationship Between Psychological Symptoms, Impulsivity and Social Media Use Problems
}

\author{
Psikolojik Belirtiler ve Dürtüsellik İle Problemli Sosyal Medya Kullanımı \\ Arasındaki İlişki
}

\author{
Ömer Tutal 1(D), Habib Erensoy 2(D), Melek Gözde Luş 3(D) \\ 1. Uskudar University Institute of Social Science, Department of Psychology , İstanbul \\ 2. Uskudar University, Faculty of Medicine, Department of Psychiatry, İstanbul \\ 3. University of Health Science, Haydarpasa Numune Training and Research Hospital, Istanbul
}

\section{ABSTRACT}

Objective: In this pilot study, the relationship between problematic social media use, impulsivity, and psychological symptoms in adults was investigated.

Method: In this study conducted with 178 people, demographic information form, Social Media Addiction Scale, Barratt Impulsiveness Scale and Brief Symptom Inventory were applied to the participants.

Results: Social media addiction levels of the participants were found to be significantly higher in women, singles, graduate graduates, those who spend more than 8 hours in social media, and Twitter and Instagram users. When the relationship between problematic social media use, impulsivity, and psychological symptoms was examined, virtual tolerance and virtual communication sub-dimensions of social media addiction were positively and significantly related to all sub-dimensions of impulsivity and psychological symptoms. In addition, the increase in the social media addiction scores of the participants was significantly predicted by the dimensions of unplanned impulsivity, depression, anxiety and somatization.

Conclusion: There are significant psychological factors that may be associated with the problematic use of social media, which has become an important part of the daily life of adults.

Keywords: Social media, addiction, impulsivity, psychological symptoms, problematic internet use

ÖZ

Amaç: Bu çalışmada yetişkinlerde problemli sosyal medya kullanımı, dürtüsellik ve psikolojik belirtiler arasındaki ilişki araştııımışıı.

Yöntem: 178 kişi ile yapılan çalışmada, araştırmayı kabul eden katılımcılara sosyo-demografik Bilgi Formu, Sosyal Medya Bağımlılı̆ı Ölçeği, Barratt Dürtüsellik Ölçeği ve Kısa Belirti Envanteri uygulanmıştır.

Bulgular: Sosyal medya bağımlılık düzeyleri çalışmamıza katılan, sosyal medyada 8 saatten fazla vakit geçiren kadın, bekar, lisansüstü mezunu katılımcılar ile Twitter ve Instagram kullanıcılarında anlamlı olarak daha yüksek bulunmuştur. Sorunlu sosyal medya kullanımı, dürtüsellik ve psikolojik belirtiler arasındaki ilişki incelendiğinde, sosyal medya bağımlılığının sanal hoşgörü ve sanal iletişim alt boyutlarının dürtüsellik ve psikolojik belirtilerin tüm alt boyutları ile pozitif ve anlamlı olarak ilişkili olduğu bulunmuştur. Ayrıca sosyal medya bağımlıı̆ının yordayıcıları incelendiğinde, katıımcıların sosyal medya bağımlılığı puanlarındaki artışın, plansız dürtüsellik, depresyon, anksiyete ve somatizasyon boyutlarılla anlamlı olarak öngörüldüğü görülmüştür.

Sonuç: Yetişkinlerin günlük yaşamının önemli bir parçası haline gelen sosyal medyanın problemli kullanımıyla ilişkilendirilebilecek önemli düzeyde psikolojik mevcuttur.

Anahtar kelimeler: Sosyal medya, bağımlıık, dürtüsellik, psikolojik belirtiler, problemli internet kullanımı 


\section{BAĞIMLILIK DERGISi - JOURNAL OF DEPENDENCE}

\section{INTRODUCTION}

Social media usage, which has become an addiction of media users of our time responds to the social demands of large masses from different cultures and all segments of society; besides, it is at the target of those who criticize these virtual environments. Today, with those of the internet, data can be spread to global audiences. The Internet also provides an opportunity for social interaction in the public and private spheres. The Golden Age of the Internet and the burgeoning scene of social media offered so much promise; internet and social media affect people's lives $(1,2)$. The development of new communication environments increase interest in information and communication technologies from all segments, increase the power of social media and add a different dimension to the concept of socialization. People use socialmedia tools to meet with their acquaintances, to look at photos of their friends, to message, to have fun in their spare time. A new trend has emerged recently with internet-based applications defined as social media. These internet applications provide an ever-increasing interaction between applicants and users through the people they are happy with (3).

The internet, which has entered our lives rapidly, has undoubtedly brought some problems with it., that these interactive environments contain dependency objects for users (4). Similar studies draw attention to the addiction caused by the intensive use of social media tools. (5-7). Concerns about having uncontrollable motivation to spend enough time and effort on socialmedia to affect other important living spaces, to use social media and to log on to were raised by various authors $(6,8)$. When describing their use of social media, people's experiences are similar to those that of criteria commonly used fo addictions (4). Excessive social media use occurs as being constantly engaged with social media to reduce negativeemotions, increasingly using the social media to achieve the same pleasure, gradually developing tolerance and preventing the use of social media and severe negative emotions appear (6). It is stated that socialmedia addiction is accompanied by socialanxiety and depressives ymptoms $(9,10)$. Some personality traits, impulsivity, shyness, low conscience and self-esteem are known to be related to addiction (11). Some studies have emphasized that there are common risk factors such as underlying impulsivity, personality disorder, based on common features in different technological addiction behaviors such as computer game addiction, internet and socialmedia addiction (12-15). In the light of the literature, this study we examined the relationship between problematic social media use, impulsivity, and psychological symptoms in adults. Our hypothesis is that there is a relationship between problematic social media use and impulsivity and psychological symptoms of adults.

\section{METHOD}

\section{Sample}

The sample of the study consists of adults randomly selected from normal society between the ages of 18-65. A survey was conducted with 178 people who agreed to participate in the research. Forms were distributed to 236 people targeted for the study and approval was requested, but only 178 people agreed to participate and signed a consent form. Inclusion criteria were completed 18 years old, be able to use social media and volunteer to have participated in the study, and exclusion criteria were Presence of any chronic medical illness, age younger than 18 years, and Presence of other psychiatric disorder including psychosis and bipolar disorder, alcohol or substance use disorder. 


\section{BAĞIMLILIK DERGISi - JOURNAL OF DEPENDENCE}

\section{Procedure}

This study protocol was approved by the Institutional Review Board of the non-invasive ethics committee of Üsküdar University, approval number 61351242/2019-504 and dated 24/10/2019. Informed consent of each participant was obtained before participating into study. All patient completed the scales and demographic form given to them.

\section{Measures \\ Sociodemographic Data Form}

In this form prepared by the responsible person, in order to learn the sociodemographic information of the participants, the participants were asked to provide their information about gender, age, marital status, education level, income level, employment status, time spent in virtual environment, and the most frequently used social media application variables.

\section{Social Media Addiction Scale - Adult Form (SMAS-AF)}

The social media scale was used to measure the level of social media addiction of individuals in the sample group. The scale was developed by Şahin and Yağcl. As a result of exploratory and confirmatory analysis, it was determined that SMAS-AF is a five likert type scale has a structure consisting of 2 sub-dimensions (virtual tolerance and virtual communication) and 20 descriptions. The factor loads of the scale are ranked between 61 and 87. In the confirmatory factor analysis performed to confirm the twofactor structure of the scale, the Chi-square value $(\chi 2=7051.32$; $s d=190, p=0.00)$ was found to be significant. Factor loads of SMAS-AF take values between 61 and 87 . Cronbach Alpha total internal consistency coefficient for the overall scale, 94; Of the sub-dimensions, 92 for virtual tolerance and 91 for virtual communication. The test-retest reliability coefficients in general, was found as 93; Among the subdimensions, it is determined as 91 for virtual tolerance and 90 for virtual communication. Analysis revealed that SMAS-AF is a valid and reliable scale for determining the social media addiction of adults.

\section{Barratt Impulsiveness Scale 11th version (BIS-11)}

Barratt Impulsivity Scale-11 (BIS-11) is a self-assessment scale developed by Patton, Stanford and Barratt to measure the impulsivity levels of individuals (17). The scale was adapted to Turkish by Güleç et al. and its validity and reliability studies were carried out (18). BIS-11 is a 4-point likert-type scale consisting of 30 items in total $(1=$ Rarely / Never, 2 = Sometimes, $3=0$ Often, 4 = Almost Always $/$ Always). BIS-11 consists of 3 subscales with good reliability. These; impulsivity related to attention, motor impulsivity and inability to plan. While evaluating BIS-11, 4 different scores are obtained, namely total score, attention and motor impulsivity and inability to plan. The high value of the total score is an indicator of higher impulsivity. In the sub-scales, the high score of the attention scale indicates that the person displays careless behaviors and makes quick decisions; the high score of the motor impulsivity subscale is the increase in motor movements and the person is acting without thinking; The high score of nonplanning subscale indicates instability in planning life. While the validity and reliability studies of BIS-11 were being conducted, the internal consistency Cronbach alpha coefficients were 0.78 for university students and 0.81 for patients. Retest reliability was found to be 0.83 in the student group.

\section{Brief Symptom Inventory (BSI)}

It is a likert-type self-assessment inventory developed by Derogatis on the need for short but valid 


\section{BAĞIMLILIK DERGISi - JOURNAL OF DEPENDENCE}

and reliable scales that will make a general psychopathology assessment (19). BSI is a short form of SCL$90-R$ that results from studies with SCL-90-R. Among the 90 items scattered across nine factors of SCL90-R, a total of 53 items with the highest load in each factor were selected and a short scale of similar structure was obtained that could be applied in 5-10 minutes. BSI consists of nine subscales, additional items and three global indexes. The subscales were named as "Somatization", "Obsessive-Compulsive Disorder", "Interpersonal Sensitivity", "Depression", "Anxiety Disorder", "Hostility", "Phobic Anxiety", "Paranoid Thoughts", "Psychotism", respectively. In the Turkish adaptation made by Şahin and Durak (1994), it was found that BSI consists of five factors: "Anxiety", "Depression", "Negative Self", "Somatization" and "Hostility" (20).

\section{Statistical Analysis}

The study was carried out with the sample to be selected with simple random sampling. Data entries of the responses of the participants, were made ready for analysis in SPSS 23.0 package program. Before the analysis, independent variables were determined as sociodemographic variables, impulsivity and psychological symptoms, including the dependent variable problem social media use determined by the researcher. For data analysis, normality tests were conducted to test whether the data showed normal distribution and parametric or non-parametric measurements were applied in line with the obtained results. For comparison analysis, parametric Independent Sample t Test or non-parametric Mann-Whitney $\mathrm{U}$ test was used to compare demographic variables containing binary groups with research variables. Kruskal Wallis H Test was used to compare sociodemographic variables with more than two independent groups. For correlational analyzes, Pearson Correlation was applied and regression analysis was performed. In the analysis, the significance value will be taken at the 0.05 level with $95 \%$ confidence.

Table 1. SMAS-AF sub-scale scores according to sociodemographic data

\begin{tabular}{|c|c|c|c|c|c|c|}
\hline SMAS-AF & & $\mathrm{N}$ & $X$ & Ss & $t$ & $p$ \\
\hline \multirow{6}{*}{ Virtual Tolerace } & Male & 88 & 21,10 & 9,809 & $-2,225$ & $027^{\star}$ \\
\hline & Female & 90 & 24,26 & 9,097 & & \\
\hline & Single & 138 & 23,92 & 9,538 & 3,257 &, $001^{\star \star}$ \\
\hline & Married & 40 & 18,48 & 8,467 & & \\
\hline & Working & 79 & 21,14 & 9,200 & $-1,957$ & ,052 \\
\hline & Unemployed & 99 & 23,94 & 9,706 & & \\
\hline \multirow{6}{*}{$\begin{array}{l}\text { Virtual } \\
\text { Communication }\end{array}$} & Male & 88 & 13,80 & 6,821 &,- 922 & ,358 \\
\hline & Female & 90 & 14,66 & 5,581 & & \\
\hline & Single & 138 & 14,95 & 6,293 & 2,924 &, $004^{\star \star}$ \\
\hline & Married & 40 & 11,75 & 5,339 & & \\
\hline & Working & 79 & 13,65 & 6,222 & $-1,121$ & 264 \\
\hline & Unemployed & 99 & 14,70 & 6,215 & & \\
\hline
\end{tabular}

\section{RESULTS}

When the sociodemographic data of the people participating in our study are examined, it is seen that $49.4 \%$ of the participants are women (88 people) and 50.6\% (90 people) are men, $77.5 \%$ (138 people) are single and $22.5 \%$ (40 people) are married. According to the education level variable, $7.3 \%$ (13 people) primary school graduates, $12.4 \%$ (22 people) high school graduates, $70.8 \%$ (126 people) undergraduate graduates and 9.6\% (17 people) graduate graduates. In addition 44.4\% (79 people) have a job and 55.6\% (99 people) do not have. Independent sample t test of SMAS-AF sub-scale scores 
according to sociodemographic data is shown in Table 1. SMAS-AF virtual tolerance subscale $(\mathrm{t}=-2,225$; $p<0.05)$ was significantly higher in women than in men. SMAS-AF virtual tolerance sub-scale $(t=3.257$; $p<0.01)$ and virtual communication ( $t=2.924 ; p<0.01)$ sub-scale scores were significantly higher than single men. It was also found that the SMDS subscales did not differ significantly in terms of working status ( $p>0.05)$.

Table 2. SMAS-AF sub-scale scores according to time variable in social media

\begin{tabular}{|c|c|c|c|c|c|c|c|c|}
\hline \multicolumn{3}{|l|}{ SMAS-AF } & $\mathrm{N}$ & $x$ & & $\mathrm{sd}$ & $p$ & Significant \\
\hline \multirow[t]{11}{*}{$\begin{array}{l}\text { Virtual } \\
\text { Tolerance }\end{array}$} & \multirow{3}{*}{$\begin{array}{l}\text { Time } \\
\text { spent } \\
\text { on } \\
\text { social } \\
\text { media } \\
\text { during } \\
\text { the day }\end{array}$} & $\begin{array}{l}\text { Less than } 5 \\
\text { hours }\end{array}$ & 122 & 82.42 & & & & \\
\hline & & 5-8 hours & 45 & 100.07 & 9.388 & 2 & $.009^{\star \star}$ & $3-1$ \\
\hline & & 8 hours or more & 11 & 124.82 & & & & \\
\hline & \multirow{4}{*}{$\begin{array}{l}\text { Social } \\
\text { media } \\
\text { tool }\end{array}$} & Facebook & 21 & 52.60 & & & & \\
\hline & & Instagram & 119 & 96.26 & 14.117 & 3 & $.003^{\star \star}$ & $2-1$ \\
\hline & & Twitter & 17 & 78.32 & & & & \\
\hline & & YouTube & 21 & 97.14 & & & & \\
\hline & \multirow{4}{*}{$\begin{array}{l}\text { Purpose } \\
\text { of social } \\
\text { media } \\
\text { use }\end{array}$} & Shopping & 7 & 108.93 & & & & \\
\hline & & Research & 62 & 88.38 & 2.508 & 3 & .474 & \\
\hline & & Communication & 67 & 84.16 & & & & \\
\hline & & Sharing & 42 & 96.43 & & & & \\
\hline \multirow[t]{11}{*}{$\begin{array}{l}\text { Virtual } \\
\text { Communication }\end{array}$} & \multirow{3}{*}{$\begin{array}{l}\text { Time } \\
\text { spent } \\
\text { on } \\
\text { social } \\
\text { media } \\
\text { during } \\
\text { the day }\end{array}$} & $\begin{array}{l}\text { Less than } 5 \\
\text { hours }\end{array}$ & 122 & 85.73 & & & & \\
\hline & & 5-8 hours & 45 & 90.98 & 6.065 & 2 & $.048^{*}$ & $3-2$ \\
\hline & & 8 hours or more & 11 & 125.32 & & & & \\
\hline & \multirow{4}{*}{$\begin{array}{l}\text { Social } \\
\text { media } \\
\text { tool }\end{array}$} & Facebook & 21 & 54.62 & & & & \\
\hline & & Instagram & 119 & 94.10 & & & & \\
\hline & & Twitter & 17 & 97.29 & 11.118 & 3 & $.011^{*}$ & $2-1$ \\
\hline & & YouTube & 21 & 92.00 & & & & \\
\hline & \multirow{4}{*}{$\begin{array}{l}\text { Purpose } \\
\text { of social } \\
\text { media } \\
\text { use }\end{array}$} & Shopping & 7 & 102.43 & & & & \\
\hline & & Research & 62 & 91.73 & & & & \\
\hline & & Communication & 67 & 87.04 & .754 & 3 & .860 & \\
\hline & & Sharing & 42 & 87.96 & & & & \\
\hline
\end{tabular}

\footnotetext{
${ }^{\star} \mathrm{p}<0.05 ;{ }^{* *} \mathrm{p}<0.01$
}

Table 2 shows taht Kruskal Wallis $\mathrm{H}$ test of SMAS-AF sub-scale scores according to time variable in social media. SMAS-AF virtual tolerance sub-scale $(Z=9,388 ; p<0,01)$ and virtual communication sub-scale $(Z=6,065 ; p<0,05)$ scores differ significantly according to the time variable spent on social media. Considering the findings of the of the dual group Mann Whitney $U$ Test conducted to determine the source of the difference, the participant's social tolerance and virtual communication sub-scale scores were significantly higher than those who spent less than 5 hours in social media. SMAS-AF sub-scales of virtual tolerance $(Z=14,117 ; p<0,01)$ and virtual communication $(Z=11,118 ; p<0,05)$ differ significantly according to the preferred social media tool variable. According to the findings of the dual group Mann Whitney U Test conducted to determine the source of the difference, the participant's stating that they use Instagram, virtual tolerance subscale scores were highest; Virtual communication subscales were significantly higher than the participants who reported using Twitter. In terms of the purpose of social 
media usage variable, SMAS-AF subscale score averages do not differ significantly ( $p>0.05)$.

Table 3. Correlation analysis of SMAS-AF, BIS-11 and BSI sub-scales

\begin{tabular}{|l|l|c|c|c|c|c|c|c|c|c|c|}
\hline Scales & Sub-scales & 1 & 2 & 3 & 4 & 5 & 6 & 7 & 8 & 9 & 10 \\
\hline $\begin{array}{l}\text { SMAS- } \\
\text { AF }\end{array}$ & Virtual tolerance & 1 & & & & & & & & & \\
\hline & $\begin{array}{l}\text { Virtual } \\
\text { communication }\end{array}$ & $.678^{* *}$ & 1 & & & & & & & & \\
\hline BIS-11 & $\begin{array}{l}\text { Attetional } \\
\text { impulsivity }\end{array}$ & $.456^{* *}$ & $.385^{* *}$ & 1 & & & & & & & \\
\hline & $\begin{array}{l}\text { Motor } \\
\text { impulsivity }\end{array}$ & $.439^{* *}$ & $.378^{* *}$ & $.601^{* *}$ & 1 & & & & & & \\
\hline & $\begin{array}{l}\text { Unplanned } \\
\text { impulsivity }\end{array}$ & $.511^{* *}$ & $.305^{* *}$ & $.562^{* *}$ & $.606^{* *}$ & 1 & & & & & \\
\hline BSI & Anxiety & $.315^{* *}$ & $.371^{* *}$ & $.414^{* *}$ & $.353^{* *}$ & $.252^{* *}$ & 1 & & & & \\
\hline & Depression & $.367^{* *}$ & $.363^{* *}$ & $.458^{* *}$ & $.380^{* *}$ & $.277^{* *}$ & $.882^{* *}$ & 1 & & & \\
\hline & Negative Self & $.314^{* *}$ & $.345^{* *}$ & $.412^{* *}$ & $.378^{* *}$ & $.258^{* *}$ & $.880^{* *}$ & $.902^{* *}$ & 1 & & \\
\hline & Somatization & $.208^{* *}$ & $.216^{* *}$ & $.368^{* *}$ & $.316^{* *}$ & $.184^{*}$ & $.840^{* *}$ & $.814^{* *}$ & $.793^{* *}$ & 1 & \\
\hline & Hostility & $.222^{* *}$ & $.211^{* *}$ & $.337^{* *}$ & $.268^{* *}$ & .113 & $.729^{* *}$ & $.783^{* *}$ & $.769^{* *}$ & $.745^{* *}$ & 1 \\
\hline
\end{tabular}

${ }^{\star \star} p<0,01{ }^{\star} p<0,05$; SMAS-AF: Social Media Addiction Scale - Adult Form; BIS-11: Barratt Impulsiveness Scale, 11th version; BSI: Brief Symptom Inventory

According to the correlation findings in Table 3, SMAS-AF virtual tolerance sub-scale and attentioan impulsivity $(r=, 456 ; p<0,01)$, motor impulsivity $(r=439 ; p<0,019$, unplanned impulsivity $(r=, 511 ; p<0,01)$, BSI anxiety $(r=, 315 ; p<0,01)$, BSI depression $(r=, 367 ; p<0,01)$, BSI negative self $(r=, 314 ; p<0,01)$, BSI somatization $(r=, 208 ; p<0,01)$ and BSI hostility $(r=, 222 ; p<0,01)$ sub-scales positively and significantly correlated.

Table 4. Linear regression analysis of the SMAS-AF virtual tolerance sub-scale by impulsivity and psychological symptoms

\begin{tabular}{|l|l|c|c|c|c|c|}
\hline \multicolumn{1}{|l|}{ Model } & \multicolumn{1}{c|}{ B } & SH & $\boldsymbol{\beta}$ & $\mathrm{t}$ & $\mathrm{p}$ \\
\hline 1 & (Constant) & 2.294 & 2.745 & & .836 & .405 \\
\hline & $\begin{array}{l}\text { Attentioanl } \\
\text { impulsivity }\end{array}$ & .340 & .221 & .132 & 1.542 & .125 \\
\hline & $\begin{array}{l}\text { Motor } \\
\text { impulsivity }\end{array}$ & .192 & .156 & .106 & 1.229 & .221 \\
\hline & $\begin{array}{l}\text { Unplanned } \\
\text { impulsivity }\end{array}$ & .434 & .116 & .313 & 3.755 & $.000^{\star \star *}$ \\
\hline & BSI anxiety & .115 & .160 & .113 & .716 & .475 \\
\hline & $\begin{array}{l}\text { BSI } \\
\text { depression }\end{array}$ & .344 & .157 & .374 & 2.196 & $.029^{\star}$ \\
\hline & $\begin{array}{l}\text { BSI negative } \\
\text { self }\end{array}$ & -.107 & .180 & -.096 & -.593 & .554 \\
\hline & $\begin{array}{l}\text { BSI } \\
\text { somatization }\end{array}$ & -.398 & .189 & -.260 & -2.103 & $.037^{\star}$ \\
\hline & BSI hostility & .012 & .207 & .006 & .058 & .954 \\
\hline & $R^{2}=0.356$ & Corrected $R^{2}=0.326$ & & & \\
\hline
\end{tabular}

${ }^{\star \star} p<0,01{ }^{\star} p<0,05$; SMAS-AF: Social Media Addiction Scale - Adult Form; BIS-11: Barratt Impulsiveness Scale, 11th version; BSI: Brief Symptom Inventory

SMAS-AF virtual communication sub-scale and attentional impulsivity $(r=, 385 ; p<0,01)$, motor implsivity ( $r=378 ; p<0,019$, unplanned impulsivity $(r=305 ; p<0,01)$, BIS-11 anxiety $(r=, 371 ; p<0,01)$, BIS-11 depression $(r=, 363 ; p<0,01)$, BSI negative self $(r=, 345 ; p<0,01)$, BSI somatization $(r=, 216$; $p<0,01)$ and BSI hostility $(r=, 211 ; p<0,01)$ sub-scales positively and significantly correlated. BIS-11 


\section{BAĞIMLILIK DERGISi - JOURNAL OF DEPENDENCE}

attentional impulsivity, BSI anxiety $(r=, 414 ; p<0,01)$ BIS depression $(r=, 458 ; p<0,01)$, BSI negative self $(r=, 412 ; p<0,01)$, BSI somatization $(r=, 368 ; p<0,01)$ and BSI hostility $(r=, 337 ; p<0,01)$ sub-scales positively and significantly correlated. BIS-11 motor impulsivity and BSI anxiety $(r=, 353 ; p<0,01)$, BSI depression ( $r=380 ; p<0,01)$, BSI negative self $(r=, 378 ; p<0,01)$, BSI somatization $(r=, 316 ; p<0,01)$ and BSI hostility $(r=, 268 ; p<0,01)$ sub-scales positively and significantly correlated. BIS-11 unplanned impulsivity and BSI anxiety ( $r=, 252 ; p<0,01)$, BSI depression $(r=, 277 ; p<0,01)$, BSI negative self $(r=, 258$; $p<0,01)$ and BSI somatization $(r=, 184 ; p<0,05)$ sub-scales positively and significantly correlated. The findings of linear regression analysis for predictive analysis of variables with correlation are given in Table 4 and Table 5.

Table 5. Linear regression analysis of the SMAS-AF virtual communication sub-scale by impulsivity and psychological symptoms

\begin{tabular}{|l|l|c|c|c|c|c|}
\hline \multicolumn{2}{|l|}{ Model } & $\mathrm{B}$ & $\mathrm{SH}$ & $\boldsymbol{\beta}$ & $\mathrm{t}$ & $\mathrm{p}$ \\
\hline 1 & (Constant) & 4.560 & 1.902 & & 2.397 & .018 \\
\hline & Attentional impulsivity & .269 & .153 & .160 & 1.759 & .080 \\
\hline & Motor impulsivity & .214 & .108 & .180 & 1.972 & .050 \\
\hline & Unplanned impulsivity & .015 & .080 & .017 & .189 & .851 \\
\hline & BSl anxiety & .272 & .111 & .409 & 2.446 & $.015^{\star}$ \\
\hline & BSI depression & .123 & .109 & .206 & 1.135 & .258 \\
\hline & BSI negative self & .017 & .124 & .023 & .135 & .893 \\
\hline & BSI somatization & -.351 & .131 & -.352 & -2.676 & $.008^{\star \star}$ \\
\hline & BSI hostility & -.137 & .144 & -.109 & -.950 & .343 \\
\hline & $R^{2}=0.270$ & Corrected $R^{2}=0.236$ & & & \\
\hline
\end{tabular}

${ }^{{ }^{*} \mathrm{p}}<0,01{ }^{*} \mathrm{p}<0,05$; SMAS-AF: Social Media Addiction Scale - Adult Form; BIS-11: Barratt Impulsiveness Scale, 11th version; BSI: Brief Symptom Inventory

\section{DISCUSSION}

In this study, the relationship between problematic social media use, impulsivity, and psychological symptoms in adults was examined. According to the findings obtained from the study, social media addiction levels were significantly higher in women, singles, graduates, those who spend more than 8 hours in social media, and twitter and instagram users. In the literature, researches more consistently of social media addiction began to show that it is more common among women than men $(21,22)$. Besides, according to the literature, not being in a relationship is positively related to addictive behavior (23). When the relationship between problematic social media use, impulsivity, and psychological symptoms was examined, it was found that virtual tolerance and virtual communication sub-scales of SMAS-AF were positively and significantly related to all sub-scales of impulsivity and psychological symptoms. In our study it was also observed that the increase in participant's social media addiction scores was significantly predicted by unplanned impulsivity, depression, anxiety and somatization scores. Social media can provide many benefits for individuals, such as staying in touch with family and friends or connecting with new friends, but it does have some risks $(24,25)$. The more time spent on social media more anxiety symptoms and depression is observed $(26,27)$. The relationship between gambling addiction, game addiction and other addiction behaviors related to Internet use disorders with impulsivity has been previously emphasized $(28,29)$. Wegmann et. al (2020) investigated the relationship between impulsivity, general executive functions, and specific inhibitory control and stated that the severity of symptoms of a social network use disorder is related to impulsivity (30). In their work, they emphasized that if there is a decrease in executive functions or inhibition control, the relationship between impulsivity and symptoms has become more 


\section{BAĞIMLILIK DERGISi - JOURNAL OF DEPENDENCE}

important. As is known, high impulsivity is associated with symptoms of internet addiction, online game addiction and gambling addiction (29.31).

In the literature, the levels of publishing positive content disproportionate to their lives and underestimating negative content are also mentioned, in line with the emotional problems of social media users (32). In our study, as well as evaluating SMAS-AF results, when it is evaluated in terms of demographic questions about social media use, it is seen that the social media application preferred by the participants, the time they spent in social media, and the purpose of social media use created significant differences in terms of psychological symptoms and impulsivity. The somatization scores of the people in our study, who use social media for research purposes, can be attributed to the possibility of being involved in social media posts or interaction groups related to their complaints.

Virtual tolerance is defined as an increase in the tolerance of people for the time spent in the virtual environment and mental occupation regarding the virtual environment (33). Virtual tolerance subscale was found higher in the participants who stated that they preferred to use Instagram. However, participants who scored highly in the virtual communication sub-scale are composed of participants who prefer to use Twitter. The reason why the obtained results differ among the social media options is that the purpose of the applications is different. While Twitter is a social media application that gives people the option of messaging different people over instant messages; Instagram is a social media platform where its visual sharing is more. While it is in the phase of developing more tolerance for people compared to the social media applications they can spend; Virtual communication dependency is more in the use of Twitter.

Accordingly, it is thought that similar studies can be repeated with different sample groups. The study was limited by small sample size, cross-sectional design, monocenter origin, it was conducted only in Istanbul and with a narrow age group. In a larger sample, it is thought that studies carried out in different provinces and on different age groups with parental participation would shed light on this area. It is thought that detailed information about the prevalence of problematic social media use can be obtained by increasing the number of samples and studies with different age groups.

In line with the findings obtained in the research, problematic social media use and impulsivity and psychological symptoms were examined in adults and it was found that problematic social media use had a significant relationship with impulsivity and psychological symptoms. Overuse of social media, which has become an indispensable element of daily life, people are not aware of; however, it can become an important problem that can lead to a number of functional problems. It is considered important to prevent this situation and to provide accurate information to individuals about social media literacy and possible risks.

\section{REFERENCES}

1. O'Murchu I, Breslin JG, Decker S, et al. Semantic social network portal for collaborative online communities. Journal of European Industrial Training. 2005; 29: 472-487.

2. Lee K, Jessica B. Virtually local: social media and community among Polish nationals in Dublin. Aslib Proceedings: 2009; 61(3): 10.1108/00012530910959790.

3. Mikail B. Yeni bir iletişim ortamı olarak sosyal medya: Ege Üniversitesi Iletişim Fakültesine yönelik bir çalışma. Journal of YasarUniversity 2010; 20: 3348-3382.

4. Zendle D, Bowden-Jones H. Is excessive use of social media an addiction? BMJ 2019; 365: I2171.

5. Andreassen CS. Online social network site addiction: a comprehensive review. Curr Addict Rep 2015; 2: 175184. 


\section{BAĞIMLILIK DERGISi - JOURNAL OF DEPENDENCE}

6. Andreassen CS, Pallesen S, Griffiths MD. The elationship between addictive use of social media, narcissism, and self-esteem: Findings from a large national survey. Addict Behav 2017; 64: 287-293.

7. Van Deursen AJ.AM., Bolle C., Hegner S, et al. Modeling habitual and addictive smartphone behavior: The role of smartphone usage types, emotional intelligence, socialstress, self-regulation, age, and gender. Comput Human Behav 2015; 45: 411-420.

8. Ellis DA, Davidson Bl, Shaw H, et al. Do smart phone usage scales predict behavior? Int J Hum Comput Stud 2019; 130: 86-92.

9. Lee-Won RJ, Herzog L, Park SG. Hooked on Facebook: the role of social anxiety and need for social assurance in problematic use of Facebook. Cyberpsychol Behav Soc Netw 2015; 18: 567-574.

10. Van Rooij AJ, Ferguson CJ, Van de Mheen D, et al. Time to abandon internet addiction? Predicting problematic internet, game, and social media use from psychosocial well-being and application use. Clin Neuropsychiatry 2017; 14: 113-121.

11. Griffiths MD. The myth of 'addictive personality'. Glob J Addict Rehabil Med 2017; 3(2): 555610

12. Robbins TW, Clark L. Behavioral addictions. Curr Opin Neurobiol 2015; 30: 66-72.

13. Sussman $S$, Arpawong TE, Sun $P$, et al. Prevalence and co-occurrence of addictive behaviors among former alternative high school youth. J Behav Addict 2014; 3: 33-40.

14. Királ, O, Griffiths MD, Urbán R, et al. Problematic internet use and problematic online gaming are not the same: Findings from a large nationally representative adolescent sample. Cyberpsychol Behav Soc Netw 2014; 17: 749-754.

15. Salehan M, Negahban A. Social networking on smartphones: When mobile phones become addictive. Comput Human Behav 2013; 29: 2632-2639.

16. Şahin C, Yağcı M. Sosyal Medya Bağımlılığı Ölçeği-Yetişkin Formu: Geçerlilik ve güvenirlik çalışması. Ahi Evran Ủniversitesi Kırşehir Eğitim Fakültesi Dergisi (KEFAD) 2017; 14: 523-538.

17. Patton JH, Stanford MS, Barratt ES. Factor structure of the Barratt impulsiveness scale. J Clin Psychol 1995; 51:768-774.

18. Güleç H, Tamam L, Yazıcı-Güleç M, et al. Psychometric properties of the Turkish version of The Barratt Impulsiveness Scale-11. Klin Psikofarmakol Bulteni 2008; 18: 251-258.

19. Derogatis LR. The Brief Symptom Inventory (BSI); Administration, scoring and procedures manual I-II. Clinical Psychometric Research , 1992.

20. Şahin NH, Durak A. Kısa Semptom Envanteri: Türk gençleri için uyarlanması. Türk Psikoloji Dergisi 1994; 9(31): $44-56$.

21. Andreassen CS. Online social network site addiction: A comprehensive review. Curr Addict Rep 2015; 2: 175184.

22. Turel 0 , Poppa NT, Gil-Or 0 . Neuroticism magnifies the detrimental association between social media addiction symptoms and wellbeing in women, but not in men: a three-way moderation model. Psychiatr Q 2018; 89: 605-619.

23. Andreassen, CS, Torsheim T, Pallesen S. Predictors of use of social network sites at work-A specific type of cyberloafing. J Comput Mediat Commun 2014; 19: 906-921.

24. O'Keeffe GS, Clarke-Pearson K, Council on Communications and Media. The impact of social media on children, adolescents, and families. Pediatrics 2011; 127: 800-804

25. Turel 0 , Brevers $D$, Bechara $A$. Time distortion when users at-risk for social media addiction engage in nonsocial media tasks. J Psychiatr Res. 2018; 97: 84-88.

26. Thorisdottir IE, Sigurvinsdottir R, Asgeirsdottir BB, et al. Active and passive social media use and symptoms of anxiety and depressed mood among icelandic adolescents. cyberpsychology, behavior, and social networking. Cyberpsychol Behav Soc Netw 2019; 22: 535-542.

27. Escobar-Viera CG, Shensa A, Bowman ND, et al. Passive and active social media use and depressive symptoms among United States adults. Cyberpsychol Behav Soc Netw 2018; 21: 437-443.

28. Ryu H, Lee J, Aruem Choi, et al. The relationship between impulsivity and Internet gaming disorder in young adults: Mediating effects of interpersonal relationships and depression. Int J Env Res Public Health 2018; 15: $1-11$,

29. Bothe B, Toth-Kiraly I, Marc N, et al. Revisiting the role of impulsivity and compulsivity in problematic sexual behaviors. J Sex Res 2018; 56: 166-179.

30. Wegmann E, Müller SM, Turel 0, et al. Interactions of impulsivity, general executive functions, and specific inhibitory control explain symptoms of social-networks-use disorder: An experimental study. Sci Rep 2020; 10: 3866. 


\section{BAĞIMLILIK DERGISI - JOURNAL OF DEPENDENCE}

31. Bargeron AH, Hormes, JM. Psychosocial correlates of Internet gaming disorder: Psychopathology, life satisfaction, andimpulsivity. Comput Human Behav 2017; 68: 388-394,

32. Thorisdottir IE, Sigurvinsdottir R, Asgeirsdottir BB, et al. Active and passive social media use and symptoms of anxiety and depressed mood among Icelandic adolescents. Cyberpsychol Behav Soc Netw 2019; 22: 535-542.

33. Wang $X$, Sun $C$. Yao $Y$, et al. Extension of the definition of tolerance and an application there of in the calculation of dimension chains Int J Adv Manuf Technol 2014; 71: 1069-1076. 